\title{
HOSPITALS SAFE FROM DISASTERS: A GLIMPSE INTO THE MEXICAN COASTAL ZONES
}

\author{
MILTON MONTEJANO-CASTILLO \& MILDRED MORENO-VILLANUEVA \\ Escuela Superior de Ingeniería y Arquitectura Unidad Tecamachalco del Instituto Politécnico Nacional, México.
}

\begin{abstract}
Flood risks and damages due to natural phenomena are becoming more frequent in Mexican coastal zones. Given this condition, the critical infrastructure of cities must be prepared and protected for such disasters, particularly in the health sector. To face this challenge, during the World Conference on Disasters Risk Reduction in 2005, the United Nations launched the global campaign 'Hospitals Safe from Disasters'. This campaign was based on the commitment that hospitals must be safe in order to mitigate disasters damages and hospitals must continue functioning after a disaster. Mexico together with other 168 countries became part of the compromise. In 2015, said goals and objectives were ratified in the Sendai Framework for Disaster Risk Reduction 2015-2030. Under the leadership of the National System for Civil Defense Mexico's, the 'Safe Hospital Program' has been a mechanism to evaluate and certify the safety of hospitals located on disaster risk areas. Such a program broadly speaking comprises a Hospital Safety Index, an Evaluation Process, and the corresponding Evaluators Committee. Against this background, the main goal of this paper is to show the results of a long-term project that has been documenting the limits, challenges and strategies that some hospitals pose in Mexican coastal zones in order to reach the goals of the said Program. This analysis bases on semi-structured interviews with key informants in hospitals exposed to hydrometeorological hazards as hurricanes and heavy rains. Results show that in spite of a very precise developed Safety Index and detailed evaluation tools, hospitals lack in many cases of the financial resources and a 'risk reduction culture', or have serious technical constraints imposed by the age of the buildings. Nevertheless, they have developed strategies that could be useful for other health care facilities in the same situation.
\end{abstract}

Keywords: coastal zones, disasters, hospitals, Mexico, risk reduction.

\section{INTRODUCTION}

On January 29, 2015, the explosion of a gas pipe inside a Mother and Children's Hospital in Mexico City caused the death of two newborns, two adults, dozens of injured and practically the complete destruction of the hospital [1]. Events like this automatically raise many questions and reflections about the safety and vulnerability in these types of buildings: Why is a Mother and Children's Hospital so vulnerable? Why was it so difficult to quickly evacuate the hospital and especially the evacuation of the newborns? Were there no safety standards to prevent this disaster from occurring? Unfortunately this situation is not new, but the questions behind this phenomenon have been changing over time.

During the decade of 1990 (dedicated to disasters risk reduction), some disasters around the world led to a series of publications on the impacts and effects that the destruction of a hospital - by either internal or external hazards - may have [2,3]. As a way to mitigate the problem, during the World Conference on Disasters Risk Reduction in 2005, the United Nations launched the global campaign 'Hospitals Safe from Disasters'. This campaign was based on the commitment that hospitals must be safe in order to mitigate disasters damages and hospitals must continue functioning after a disaster at least three days after it occurred; therefore, the three criteria that a safe hospital must meet are: the protection of life, the protection of the investment and the protection of the function [4]. Thus, in order to certify a hospital as safe, a series of measurable structural (physical security) and non-structural (organizational) assessment criteria were developed. Such criteria are expressed in a Safety 
Index that do date has already been revised and published as a second version [5]. Furthermore, as governments began to focus on measuring the safety of hospitals, the academic sector in many countries began to investigate the vulnerability of hospitals to 'old risks' (i.e. vulnerability to floods and earthquakes), and more recently the risks and vulnerabilities associated with climate change. Complementing the research on hospital risks and vulnerabilities another field of research was developed; one that has to do with risk management in hospitals and has as main question how to overcome the barriers to manage risk in hospitals and the assessment of official risk reduction programs (see Table 1).

Table 1: Main subjects around the safety and vulnerability of hospitals as a field of research. (Source: own elaboration based on the cited references.)

\begin{tabular}{|c|c|c|c|}
\hline Main questions & Main objectives & Countries & Authors (examples) \\
\hline $\begin{array}{l}\text { What are the } \\
\text { impacts and } \\
\text { consequences } \\
\text { of disasters in } \\
\text { hospitals? }\end{array}$ & $\begin{array}{l}\text { To make emphasis on } \\
\text { the need of a multidis- } \\
\text { ciplinary approach to } \\
\text { understand and solve } \\
\text { the problem }\end{array}$ & $\begin{array}{l}\text { Latin America and } \\
\text { the Caribbean }\end{array}$ & ONU/CEPAL [3] \\
\hline $\begin{array}{l}\text { How safe is a } \\
\text { hospital and } \\
\text { what does safe } \\
\text { mean? }\end{array}$ & $\begin{array}{l}\text { Elaborating and apply- } \\
\text { ing a hospital safety } \\
\text { index }\end{array}$ & $\begin{array}{l}\text { Mainly Latin } \\
\text { America and the } \\
\text { Caribbean }\end{array}$ & WHO/PAHO [5] \\
\hline $\begin{array}{l}\text { How vulnerable } \\
\text { is a hospital? }\end{array}$ & $\begin{array}{l}\text { Seismic vulnerability } \\
\text { assessment }\end{array}$ & $\begin{array}{l}\text { India } \\
\text { Mexico }\end{array}$ & $\begin{array}{l}\text { Rautela et al. [6] } \\
\text { Moran-Rodríguez \& } \\
\text { Novelo-Casanova [7] }\end{array}$ \\
\hline \multirow[t]{2}{*}{$\begin{array}{l}\text { (Risk and } \\
\text { vulnerability } \\
\text { assessment) }\end{array}$} & $\begin{array}{l}\text { Flood risk assessment } \\
\text { Assessment of disaster } \\
\text { preparedness }\end{array}$ & $\begin{array}{l}\text { Sudan } \\
\text { Saudi Arabia } \\
\text { Japan }\end{array}$ & $\begin{array}{l}\text { Abbas \& Routray [8] } \\
\text { Bajow \& Alkhalil [9] } \\
\text { Mulyasari et al. [10] }\end{array}$ \\
\hline & $\begin{array}{l}\text { Climate change risks } \\
\text { assessment }\end{array}$ & $\begin{array}{l}\text { Australia and New } \\
\text { Zealand }\end{array}$ & Loosemore et al. [11] \\
\hline $\begin{array}{l}\text { How well have } \\
\text { risk reduction } \\
\text { programs been } \\
\text { implemented }\end{array}$ & $\begin{array}{l}\text { Assessing implementa- } \\
\text { tion of activities aimed } \\
\text { at reducing disaster } \\
\text { risks }\end{array}$ & $\begin{array}{l}\text { Cambodia, Lao } \\
\text { PDR, the Philip- } \\
\text { pines and Viet Nam }\end{array}$ & $\begin{array}{l}\text { Geroy \& Pesigan } \\
{[12]}\end{array}$ \\
\hline $\begin{array}{l}\text { and how to } \\
\text { overcome } \\
\text { barriers to }\end{array}$ & $\begin{array}{l}\text { Assessing implemen- } \\
\text { tation of training in } \\
\text { emergencies }\end{array}$ & Mexico & Cruz-Vega et al. [13] \\
\hline $\begin{array}{l}\text { achieve imple- } \\
\text { mentation? }\end{array}$ & $\begin{array}{l}\text { To identify barriers and } \\
\text { strategies to increase } \\
\text { safety }\end{array}$ & Iran & $\begin{array}{l}\text { Yarmohammadian } \\
\text { et al. }[14]\end{array}$ \\
\hline \multirow[t]{2}{*}{$\begin{array}{l}\text { (Risk manage- } \\
\text { ment) }\end{array}$} & $\begin{array}{l}\text { To explore resilience } \\
\text { strategies }\end{array}$ & $\begin{array}{l}\text { United Kingdom } \\
\text { and Taiwan }\end{array}$ & Achour \& Price [15] \\
\hline & $\begin{array}{l}\text { To identify and docu- } \\
\text { ment successful } \\
\text { experiences to makes } \\
\text { hospitals safe }\end{array}$ & $\begin{array}{l}\text { Argentina, Bolivia, } \\
\text { Colombia, Chile, } \\
\text { Ecuador, Paraguay } \\
\text { and Perú }\end{array}$ & OPS/OMS [16] \\
\hline
\end{tabular}


It is in the last area of research that this paper inserts as a first approach to document the difficulties and success of risk management in Mexican hospitals, given the scarce literature on the subject in this country.

\section{THE SAFE HOSPITALS PROGRAM IN MEXICO}

The goal to achieve safe hospitals set out in the Hyogo Framework for Action in 2005- and ratified later in Sendai for 2015-2030 [17] - was accepted and signed by 168 countries, including Mexico. Thus, through the National System of Mexican Civil Protection, the Safe Hospital program in Mexico has been establishing since 2006 the instruments, procedures and mechanisms to evaluate and certify the level of safety of a hospital in areas subject to disaster risk in the entire Health System of Mexico. When evaluated, hospitals may be certified in the following three levels of safety [18]:

1. Index Score A means a good safety level but measures must continue to be taken in the medium and long term.

2. Index Score B is given to hospitals when short-term measures are required.

3. Index Score $C$ is given to hospitals that have to undertake urgent measures immediately.

The purpose of assigning those scores is to know what kind of hospitals are available in case of disaster in order to apply the 'Triage' system (classification of patients immediately after the disaster): if the best equipped hospitals (essential hospitals) meet all safety requirements, they would be identified as 'red hospitals' because they will be safe and able to receive patients in a critical health condition and can perform complex operations that require special equipment and specialized medical staff. If hospitals are safe but have less infrastructure, they would be classified as 'green hospitals': they could receive patients who are discharged from the red hospitals but cannot perform complex medical tasks. Finally, if hospitals are safe but have just the basic medical equipment, they would be classified as "yellow hospitals" to receive patients for the most basic health functions in case of disaster.

To organize the evaluation of hospitals, the Mexican government divided the National Health System (made up of more than 3,000 hospitals) into three levels of complexity: low, medium and high complexity, the latter corresponding to hospitals that have the capacity to receive and operate victims of a disaster in a critical condition, because they have a certain number of operating rooms, beds, X-rays, Laboratory, ATLS-trained Doctors (Advance Trauma Life Support Course) and other requirements (see Fig. 1).

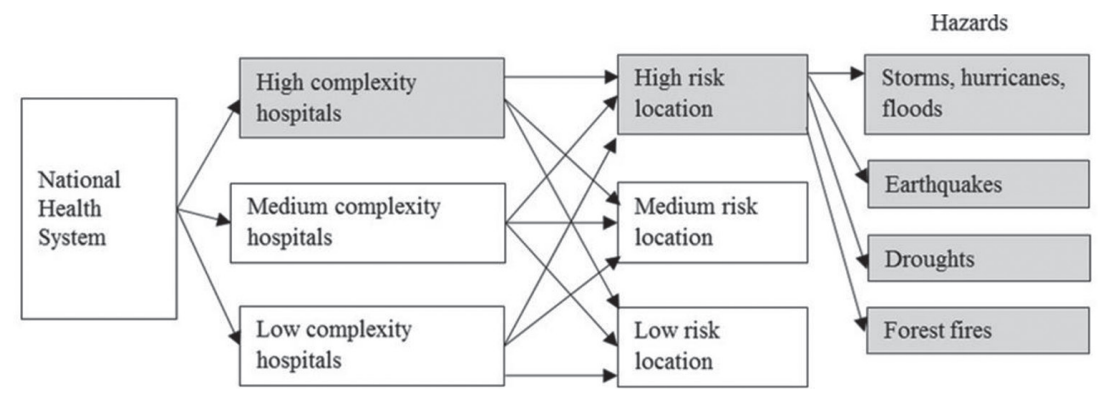

Figure 1: Organization of hospitals for evaluation into the Safety Hospitals Program in Mexico. Priority in grey. (Source: own elaboration based on CVOED/IMSS.) 
Each one of these groups of hospitals (high, medium and low complexity) are located in territories with a different degree of risk: high risk, medium risk and low risk. The risk classification of hospitals was done by states, and it was based on a National Risk Atlas, recalling that in Mexico the exposure to hazards is differentiated and those risks still overlap: $41 \%$ of the national territory is exposed to hydrometeorological hazards (Storm, hurricanes and floods), $27 \%$ of the territory is exposed to earthquakes; $29 \%$ is exposed to drought and $37 \%$ is exposed to forest fires [19].

As far as we know, there is no an official or academic publication to show the results of the evaluation at the national level and there are just isolated data. It is known, for example, that from 2007 to 2013, 515 hospitals have been evaluated but the results of that classification (score of safety) is unknown [20]. In addition to these few data, in our bibliographical search there were very few publications about the vulnerability of hospitals in Mexico and no publication was found about the risk management in health facilities, so this work may show a first approach to the advances and obstacles of the implementation of the Safe Hospital Program in Mexico.

\section{FLOOD RISK MANAGEMENT IN MEXICAN HOSPITALS}

Given the regular presence of hurricanes in Mexico and the damages that result from them year after year, it was the intention of the authors of this paper to explore the effectiveness or the difficulty in achieving an acceptable level of safety in Mexican hospitals exposed to hydro-meteorological hazards in coastal zones. Such areas represent a very important tourist destination because of the natural and cultural heritage they have and the economic resources they generate, but they are also a vulnerable area for the population that lives there and whose livelihood depends directly from the touristic affluence.

For the selection of the case studies, we considered first the list of the hospitals classified as the ones of high complexity and high resolution according to the Safe Hospital Program Mexico's. This list contained a total of 201 hospitals in 2011 [21]. From that list we selected then the hospitals of cities affected by hurricanes in the last years (see Fig. 2). Based on this information and the availability of human and financial resources to travel there, we selected the states of Colima, Jalisco, Chiapas and Tabasco. In each one of these hospitals interviews were carried out on site with emergency managers responsible for the Safe Hospitals Program.
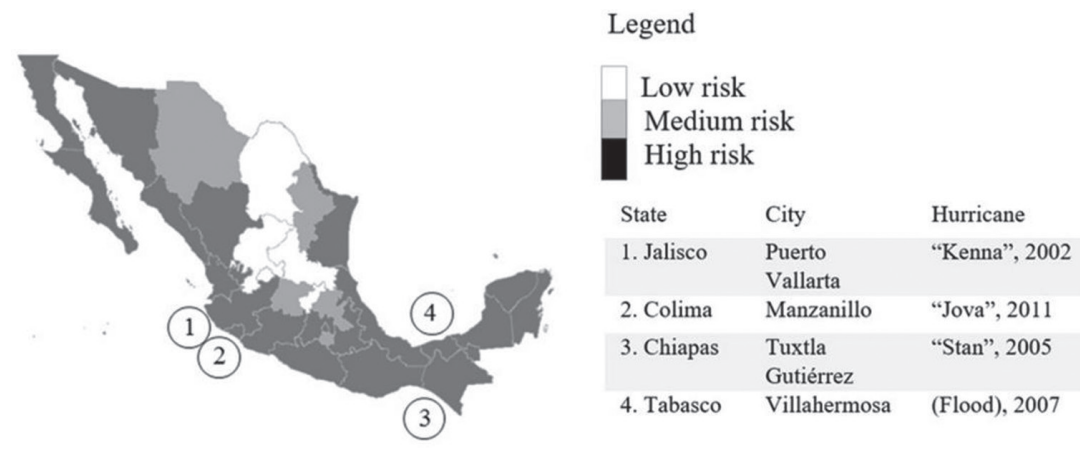

Figure 2: Risk map of Mexico and some of the States affected by hurricanes or floods in the last years. (Source: own elaboration based on CVOED/IMSS.) 
To carry out these interviews a questionnaire was formulated in order to document the existing barriers (internal or external) to the implementation of the program as well as the actions and strategies to overcome them; this method was based on the methodology proposed by Yarmohammadian et al. [14]. In the absence of a detailed list of hospitals evaluated and/or certified as safe hospitals, this question was the first one of the questionnaire. After obtaining the information in the field, the answers were classified by barriers and strategies before, during and after a flood.

A total of 10 hospitals were documented, representing four different States and four different institutions. We maintained the identity of the respondents anonymous so that no institution is compromised. The sample may seem small but the hospitals are the best equipped and there are just a few of them in each State. That is to say, in the majority of the States, just two or three hospitals are ranked as the ones of high complexity.

\subsection{Main differences between hospitals}

The first step to analyze the interviews was to make a differentiation between hospitals with scarce works for certification and hospitals with advanced works for certification (see Table 2). Among the first ones are those hospitals between 40 and 50 years old, for which it is no longer possible or would be too expensive a structural adaptation (stairs, elevators, ramps, etc.) in order to comply with the guidelines of the safe hospital Program; therefore for some of those hospitals the total abandonment of the building is already considered to be replaced by a new hospital even in another location. On the other group, hospitals that have been built more recently (from 5 to 20 years old) have an infrastructure that from the beginning allows them to adjust more easily to the security requirements; nevertheless this condition does not exempt them from having internal risks (i.e. derived from the equipment they handle), external risks, or even new risks such as organized crime. It was reported that in the case of some territories, it is common for the hospital to receive a patient that was victim of a criminal act, and who is in danger of being shot again at the hospital by a criminal group. This is a situation that puts at risk the medical staff. For this reason, one of the doctors is even submitting a normative protocol to ensure the life of the patient and the hospital staff.

A notable difference is the impact that both types of hospitals have received after a flood due to the presence of hurricanes or torrential rains. While better prepared hospitals have had only small leaks of water on ceilings or walls, unprepared hospitals had completely evacuated the building and taken patients to other hospitals. However, a common affectation to both types of hospitals during a flood is the lack of accessibility to the hospital because the streets surrounding it are flooded.

With regard to the management of the hospital, those responsible for the implementation of the Safe Hospital Program may be doctors, architects, or administrative personnel involved in civil protection. Their years of experience do not make a difference in both cases, although the knowledge about the Safe Hospital Program does. In certified hospitals or close to certification, some risk managers know the Program perfectly because they themselves are evaluators and they have evaluated other health facilities. This knowledge allows them to have a very clear vision of the tasks that must be done to increase the safety on a precise goals hierarchy and in a very timely manner (for example, budget needed to reinforce the hospital infrastructure, evidences of the drills performed, specialized equipment acquired, and equipment needed in the emergency area, dates of the next evaluation, etc.). On the other hand, in the less prepared hospitals, it was commented that they lack of evaluators or the staff is just next to receive the training to understand the functions and components of the same. 
Table 2: Comparison of Mexican Hospitals according to requirements compliance in the Safe Hospitals Program. (Source: Own elaboration based on interviews to hospital emergency managers.)

\begin{tabular}{|c|c|c|}
\hline Characteristics & $\begin{array}{l}\text { Hospitals with scarce works } \\
\text { for certification }\end{array}$ & $\begin{array}{l}\text { Hospitals with advanced } \\
\text { works for certification }\end{array}$ \\
\hline Age of the building & Around $40-50$ years old & Around 20 years \\
\hline Internal risks reported & $\begin{array}{l}\text { Explosion risk of hermetic } \\
\text { equipment (boilers, auto- } \\
\text { claves) and explosions risks } \\
\text { derived from chemicals and } \\
\text { energy supply accidents. }\end{array}$ & $\begin{array}{l}\text { Fire risk, gas installations and } \\
\text { chemicals (explosion risks). }\end{array}$ \\
\hline External risks reported & $\begin{array}{l}\text { Flood risk, earthquake risk, } \\
\text { torrential rains, gas explo- } \\
\text { sions, gas stations, epidemics, } \\
\text { and the proximity to massive } \\
\text { concentration of people in } \\
\text { public spaces like parks and } \\
\text { markets. }\end{array}$ & $\begin{array}{l}\text { Proximity to a river, proximity } \\
\text { to gas stations, proximity to } \\
\text { boilers of supermarkets in the } \\
\text { surroundings, geological risks, } \\
\text { organized crime. }\end{array}$ \\
\hline \multirow[t]{2}{*}{$\begin{array}{l}\text { Type of damages as a } \\
\text { consequence of past } \\
\text { disasters }\end{array}$} & $\begin{array}{l}\text { Flood into the hospital during } \\
\text { hurricanes, } \\
\text { Disruption of hospital activi- } \\
\text { ties or the complete evacua- } \\
\text { tion of patients during floods. } \\
\text { Reception of patients from } \\
\text { other hospitals. }\end{array}$ & $\begin{array}{l}\text { Minimum damages in ceilings } \\
\text { and walls (leaks). }\end{array}$ \\
\hline & $\begin{array}{l}\text { Lack of accessibility from the } \\
\text { outside. }\end{array}$ & $\begin{array}{l}\text { Lack of accessibility from the } \\
\text { outside in case of flood. }\end{array}$ \\
\hline $\begin{array}{l}\text { Degree of knowledge } \\
\text { of the Safe Hospital } \\
\text { Program }\end{array}$ & $\begin{array}{l}\text { Variable knowledge of the } \\
\text { Program. }\end{array}$ & $\begin{array}{l}\text { Very good knowledge of the } \\
\text { Program. }\end{array}$ \\
\hline $\begin{array}{l}\text { Certified evaluators as } \\
\text { part of the hospital staff }\end{array}$ & $\begin{array}{l}\text { There are no certified evalua- } \\
\text { tors in the hospital. }\end{array}$ & $\begin{array}{l}\text { The hospital staff themselves } \\
\text { are evaluators of the Safe } \\
\text { Hospital Program. }\end{array}$ \\
\hline $\begin{array}{l}\text { Years of experience of } \\
\text { the safety manager at the } \\
\text { hospital }\end{array}$ & Variable & Variable \\
\hline $\begin{array}{l}\text { Field of expertise of the } \\
\text { emergency manager }\end{array}$ & Variable & Variable \\
\hline $\begin{array}{l}\text { Detailed record of done } \\
\text { and pendant tasks to } \\
\text { compel with the Safe } \\
\text { Hospital Program re- } \\
\text { quirements }\end{array}$ & $\begin{array}{l}\text { Diffuse goals to increase the } \\
\text { safety of the hospital. }\end{array}$ & $\begin{array}{l}\text { Clear record of the tasks done } \\
\text { to increase the safety of the } \\
\text { hospital with evidences shown } \\
\text { to the interviewer. }\end{array}$ \\
\hline Relocation plans & $\begin{array}{l}\text { Relocation plan for the older } \\
\text { hospitals. }\end{array}$ & No plans. \\
\hline
\end{tabular}




\subsection{Barriers and Strategies for the Safe Hospital Program Certification}

The age of the hospital, in addition to the - above mentioned - structural constraints also imposes barriers to the growth of the hospital for both permanent growth (i.e. new emergency rooms) and the emergency expansion that would allow the growth of the hospital, that is to say, a provisional growth to let the hospital expand temporarily to receive massive victims. The inability to expand the hospital also does not allow a growing number of patients to be treated, which keeps the hospital in permanent overpopulation, reducing the probability of receiving more patients in critical situations (see Table 3).

Administratively, the fact that the Safe Hospitals Program it is not completely mandatory, that impedes risk reduction actions from being a priority. In other cases there are already plans but they do not have a continuity due the change of administrations or they just require too much paperwork to be implemented. In addition staff must organize their time among many other responsibilities due to the lack of staff. As a consequence a reactive attitude towards risk reduction prevails over a preventive one.

Financial reasons were reported as another impediment to certifying the hospital. Since there is no specific budget for this program, this makes it difficult to the hospital to pay some technical works. An example of this is the technical opinions about the structural safety of the building. In addition, the lack of budget also makes it difficult to update some equipment or hire more staff or built more rooms to expand the hospital.

Finally, in almost all hospitals, a reactive and non-preventive attitude is one of the obstacles that prevent hospital staff from getting involved in the hospital's safety work. Certainly the economic part is fundamental to solve needs and increase the safety in hospitals, but one way to maximize the scarce economic resources is that investments in the emergency area (structural and non-structural) can also be planned to be useful for disaster preparedness, as stated by the respondents (see Table 4). An example of this is the expansion of the emergency area that considers decontamination requirements or the availability of medical equipment differentiated between children and adults in case of emergencies or disasters.

On the other hand, in spite of the economic restrictions that every institution faces, fortunately many nonstructural strategies were documented that are not necessarily expensive and can be done before, during or after a flood and just require a certain level of organization (see Tables 4 and 5). Examples of those measures are: risk mapping around the hospital that can be done by the same medical staff; emergency drills and drills for the use of the Triage system for the classification of patients in case of disaster; an internal plan for emergencies and above all the communication and coordination with civil protection authorities before and during a disaster. A fundamental aspect to implement the said strategies is the certification of evaluators of the Safe Hospital Program, which is a free course and that enables the medical staff to organize and execute this type of tasks.

For taking the evaluator course it is not necessarily a requirement to be a doctor or an emergency specialist, since each professional acquires an overview of the program but can deepen and contribute from his/her respective area of work: medicine, emergency, nursing, administration, engineering, construction or other fields. Indeed, the multidisciplinarity is a strength of the Program because each specialist focuses on his/her field of experience during an evaluation (i.e. the engineers focus on the structural aspects of the hospital).

An aspect that may help to solve some of the said barriers is the fact that the Safe Hospital Program was already established in the Mexican General Law on Civil Protection published in 2012 [22], and in the Official Mexican Norm NOM-016-SSA3-2012, that establishes the 
Table 3: Barriers to comply with the Safe Hospitals Program in Mexican coastal zones. (Source: Own elaboration based on interviews to hospital emergency managers.)

Type of barriers Barriers to increase safety

Technical and physical factors
Institutional factors

Financial factors

Human factors
At the time of construction of the hospital there were no zoning laws and the hospital was built too close to the river.

Hospital was built before the paving of the streets. As a consequence, the street level is higher than the one of the hospital and water enters the building during heavy rains.

Age of the building. Due to the period of construction the hospital does not have ramps to enable evacuation, it lacks of elevators and stairs of emergency, etc.

Lack of space for regular activities and emergency expansion.

Overpopulation of hospitalized patients (they function at $300 \%$ of the capacity). Lack of beds. In case of disaster, they cannot receive patients. Neighbour hospitals are in the same situation. Inaccessibility to the hospital in case of disasters.

Reactive maintenance to equipment rather than preventive maintenance.

Evacuation routes and identification of safe areas inside the hospital are not defined or not complete defined.

There are other priorities and the Safe Hospital Program is not a mandatory program.

In some cases lack of commitment from hospital authorities. Only reactive responses.

The existing disaster preparedness remains just at a planning level. There are no continuity of plans because of the change of the authorities.

The existing plans are focused on emergency and not on prevention.

There are no enough staff hospital and more time is required to attend the program needs and requirements.

Lack of experts to evaluate the hospital safety.

Bureaucracy as an obstacle of the safety works.

The requirements for certification are completed but there is still no an official request to certify.

Lack of protocols for some kind of risks (i.e. how to deal with victims of organized crime.

There is no a specific budget to the Safe Hospital Program.

Scarcity of financial resources.

In a pre-evaluation, the cost of expert/technical opinions on structural, energy, electrical and gas installations is very expensive.

There are no enough medical equipment.

The existent equipment cannot be updated.

There is no a 'culture of risk'. Reactive instead of preventive responses. Lack of commitment from hospital staff.

Interest in prevention actions just in the aftermath of the disaster. 
Table 4: Strategies to reduce vulnerability to floods in Mexican hospitals in coastal zones and the main resources required. (Source: Own elaboration based on interviews to hospital emergency managers.)

Strategy to reduce vulnerability/Main resource required: $\mathrm{F}=$ Financial; $\mathrm{O}=$ Organizational

Before the flood

Structural strategies

To have several entrances to the hospital to enable accessibility.

To expand the Emergency Room considering disaster preparedness too (for example a decontamination room with enough room for the patient stretcher).

A differential equipment in the emergency room for children and adult patients.

Adaptation of the street to serve as a dam to prevent water from entering the hospital.

Construction of a retaining wall close to rivers (with the support of the municipality).

Non-structural strategies

Elaboration of hazards maps around the hospital (500 meters around) produced by

the hospital staff.

To have and to follow a plan for -permanent- expansion/construction of the hospital.

To have a plan for emergency/temporal expansion with a triage system (an

emergency expansion of at least 100\%).

Commitment of the hospital staff according to their own experience and field of

knowledge.

Permanent management to get resources and get financing from other institutions.

To motivate the staff to become evaluators.

Physicians with ATLS training (Advance Trauma Life Support), a special training for doctors.

Training courses for the hospital staff.

To make mandatory some of the activities to prepare the certification.

To define emergency brigades (fire brigade, for example).

Periodical and permanent drills of evacuation during flood and earthquakes

(involving staff and patients).

Drill of patients-decontamination (chemical-biological).

Rope Descent/Rope rescue of patients (staff is at random selected for the drill once a year).

Cardiopulmonary resuscitation training and drills.

Plan of response during floods.

To perform Tsunami drill in coordination with authorities of civil protection and other hospitals of the region.

A precise diagnostics of the state of crucial machinery in case of disaster (water, energy, fire extinguishers, and so on).

To exchange risk management plans and strategies with other hospitals.

Before a heavy precipitation, portable water pumps are transferred to the hospital to suction water during flood.

Insurance of the hospital.

To elaborate an internal plan for emergencies and civil protection (for evacuation). 
Table 5: Strategies to reduce vulnerability to floods in Mexican hospitals in coastal zones and the main resources required. (Source: Own elaboration based on interviews to hospital emergency managers.)

Strategy to reduce vulnerability/Main resource required: $\mathrm{F}=$ Financial; $\mathrm{O}=$ Organizational

During the flood

Non-Structural strategies

Maintain communications with civil protection to evacuate staff and patients on

time, if necessary.

If necessary, to evacuate patients and hospital staff to other hospitals.

Triage system after evacuation

The hospital staff organizes to take care of the evacuated patients.

Structural strategies

If necessary, to rent another facility to give continuity of operations to the health care.

After the flood

Structural strategies

Technical inspection of the building structure after the flood to guarantee the safety.

To build a new hospital (as an extreme solution)

minimum characteristics of infrastructure and equipment for hospitals and specialized medical practices, and where the Checklist to apply the Safety Index appears [23].

\section{CONCLUSIONS}

The certification within the Safe Hospital Program represents a great challenge for any hospital in any institution because it involves a large number of aspects of a technical, administrative and financial nature; above all the implementation of the program demands a preventive attitude. The identified barriers should not be underestimated, as there are many other priorities in a highly complex hospital. In this sense, the institutional guidelines for making hospitals safe would require a more coercive character, so that recommendations to reduce vulnerability were actually implemented. At the same time, more financial resources are required to retrofit or, if necessary, replace inadequate hospitals with new infrastructure; it was observed that the age of hospitals is a strong limitation when new interventions or expansion is needed. Therefore, financial instruments for prevention and reinforcement should be a fundamental component in federal and institutional programs. The historical memory of the disaster also seems to be very important, as hospitals that have been impacted by disasters recently seem to be more aware of the need to prepare. Keeping in mind the occurrence of past damage could be an important point for the promotion of a culture of risk reduction. This reinforcement should involve the different levels of the hospital, both operational and managerial. Within the field of architecture there are many things that can be done too, both for the adaptation of old hospitals as well as for the creation of new paradigms of hospital design to accommodate the new requirements, not only those ones related to safety but also the possibilities to be flexible and adaptable to new and changing circumstances. 


\section{ACKNOWLEDGEMENTS}

The authors of this paper are especially grateful to Dr. Sergio Germán Burgos Salcedo for having shared with us his great experience and deep knowledge on the safety of hospitals, particularly in the strategies part. We also thank Dulce Mara Rojas García, Adriana Jiménez Leyva and Francisco Javier Pérez Madrigal for their support in conducting some of the interviews. This article is a product of the research project IPN-SIP 20144135, funded by the Secretaría de Investigación y Posgrado del Instituto Politécnico Nacional.

\section{REFERENCES}

[1] Véliz-Pintos, R.A., Reflexiones de un pediatra ante la explosión de gas en un Hospital Materno Infantil de la Ciudad de México. Revista Mexicana de Pediatría, 82(1), pp. 3-4, available at www.medigraphic.com/pdfs/pediat/sp-2015/sp151a.pdf, 2015 (accessed 16 December 2016).

[2] Organización Panamericana de la Salud, Conferencia Internacional sobre Mitigación de Desastres en Instalaciones de Salud, available at www.paho.org/disasters/ index.php?option=com_content\&view $=$ article $\&$ id $=664$ :international-conferenceon-disaster-mitigation-in-heath-facilities\&Itemid=924\&lang=es (accessed 08 January 2015).

[3] ONU/CEPAL, Impacto Económico de los Desastres Naturales en la Infraestructura de Salud; ONU/CEPAL: México, 1996.

[4] International Strategy for Disaster Reduction/World Health Organization/World Bank, Hospitals Safe from Disasters, Reduce Risk, Protect Health Facilities, Save Lives, 2008-2009 World Disaster Reduction Campaign, ISRD/WHO/World Bank, available at www.unisdr.org/files/1347_wdrc20082009informationkit.pdf (accessed 16 December 2016).

[5] World Health Organization/Pan American Health Organization. Hospital Safety Index: Guide for Evaluators - 2nd ed., WHO: Geneva, available at www.who.int/hac/techguidance/hospital_safety_index_evaluators.pdf?ua=1, 2015 (accessed 07 September 2016).

[6] Rautela, P., Girish C.J. \& Bhupendra, B., Seismic vulnerability of the health infrastructure in the Himalayan township of Mussoorie, Uttarakhand, India. International Journal of Disaster Resilience in the Built Environment, 2(3), pp. 200-209, 2011. https://doi.org/10.1108/17595901111167088

[7] Morán-Rodríguez, S. \& Novelo-Casanova, D.A., Seismic vulnerability assessment of Health facilities in Mexico City, Mexico. WIT Transactions on The Built Environment, vol 150, WIT Press, available at www.witpress.com/elibrary/wit-transactions-on-thebuilt-environment/150/33931, 2015 (accessed 05 September 2016).

[8] Abbas, H.B. \& Routray, J.K., A semi-quantitative risk assessment model of primary health care service interruption during flood: case study of Aroma locality, Kassala State of Sudan. International Journal of Disaster Risk Reduction, 6, pp. 118-128, 2013. http://dx.doi.org/10.1016/j.ijdrr.2013.10.002

[9] Bajow, N.A. \& Alkhalil, S.M., Evaluation and analysis of hospital disaster preparedness in Jeddah. Health, 6, pp. 2668-2687, 2014.

http://dx.doi.org/10.4236/health.2014.619306 
[10] Mulyasari, F., Satomi, I., S., Prashar, S., Isayama, K., Basu, M., Srivastava, N. \& Shaw, R., Disaster preparedness: looking through the lens of hospitals in Japan. International Journal of Disaster Risk Science, 4(2), pp. 89-100, 2013. Available at: https://link. springer.com/article/10.1007/s13753-013-0010-1 (accessed 28 October 2014). https://doi.org/10.1007/s13753-013-0010-1

[11] Loosemore, M., Carthey, J., Chandra, V. \& Chand, A.M., Climate change risks and opportunities in hospital adaptation. International Journal of Disaster Resilience in the Built Environment, 2(3), pp. 210-221, 2011. http://dx.doi.org/10.1108/17595901111167097

[12] Geroy, L.S.A. \& Pesigan, A.M., Disaster risk reduction for health facilities in the Western Pacific Region. International Journal of Disaster Resilience in the Built Environment, 2(3), pp. 268-277, 2011. https://doi.org/10.1108/17595901111167132

[13] Cruz-Vega, F., Loría-Castellanos, J., Hernández-Olivas, I.P., Franco-Bey, R., OchoaÁvila, C. \& Sánchez-Badillo, V., Experiencia en capacitación en emergencias de la División de Proyectos Especiales en Salud, Instituto Mexicano del Seguro Social. Cirugía y Cirujanos, 84(2), pp. 127-134, 2016. Available at: http://www.sciencedirect. com/science/article/pii/S0009741115002881 (accessed 13 September 2016). https://doi.org/10.1016/j.circir.2015.12.001

[14] Yarmohammadian, M.H., Atighechian, G., Shams, L. \& Haghshenas, A., Are hospitals ready to response to disasters? Challenges, opportunities and strategies of Hospital Emergency Incident Command System (HEICS). Journal of Research in Medical Sciences, 16(8), 1070-1077, 2011. Available at: www.ncbi.nlm.nih.gov/pmc/articles/ PMC3263085/. (accessed 16 June 2014).

[15] Achour, N. \& Price, A.D.F., Resilience strategies of healthcare facilities: present and future. International Journal of Disaster Resilience in the Built Environment, 1(3), pp. 264-276, 2010.

https://doi.org/10.1108/17595901011080869

[16] Organización Panamericana de la Salud/Organización Mundial de la Salud, Comunidades Resilientes a través de Redes de Salud Seguras frente a Desastres en América del Sur, OPS/OMS, available at www.cridlac.org/digitalizacion/pdf/spa/doc19246/ doc19246-contenido.pdf, 2012 (accessed 13 September 2016).

[17] UNISDR (United Nations International Strategy for Disaster Reduction). Sendai Framework for Disaster Risk Reduction 2015-2030, available at: www.preventionweb. net/files/43291_sendaiframeworkfordrren.pdf, 2015 (accessed 13 September 2016).

[18] Cruz, Felipe, Mexico: Applying the "Hospital Safety Index", available at http://safehospitals.info/index.php?option=com_content\&task=view\&id=119\&Itemid=188， 2009 (accessed 28 January 2014).

[19] SEGOB/Banco Mundial, FONDEN: Mexico's Natural Disaster Fund - A Review. The International Bank for Reconstruction and Development/The World Bank, p. 3, available at: www.proteccioncivil.gob.mx/work/models/ProteccionCivil/Almacen/fonden_ resumen_ejecutivo.pdf, 2012 (accessed 12 June 2013). 
[20] Centro Virtual de Operaciones en Emergencias y Desastres (CVOED). División de Proyectos Especiales en Salud. Dirección de Prestaciones Médicas, Instituto Mexicano del Seguro Social (IMSS), available at http://cvoed.imss.gob.mx/COED/home/normativos/DPM/capacitacion/curso_taller_evacuacion/3.\%20HOSPITAL\%20SEGURO.pdf (accessed 18 January 2015).

[21] Coordinación de Protección Civil, Universo de hospitales clasificados como de alta complejidad y alto nivel resolutivo (rojos). Programa Hospital Seguro, México, available at www.proteccioncivil.gob.mx/work/models/ProteccionCivil/Resource/59/2/ images/lhcr.pdf (accessed 18 January 2015).

[22] Gobierno de México. Ley General de Protección Civil. Cámara de Diputados.

[23] Gobierno de México. Secretaría de Salud. Ley Norma Oficial Mexicana NOM-016SSA3-2012, Que establece las características mínimas de infraestructura y equipamiento de hospitales y consultorios de atención médica especializada. 